\title{
Evaluation of mungbean [Vigna radiata (L.) Wilczek] varieties under water deficit stress
}

\author{
Diksha Kumari \& Dipjyoti Chakraborty ${ }^{*}$ \\ Department of Bioscience and Biotechnology, Banasthali Vidyapith, Rajasthan 304 022, India
}

\section{Article history}

Received: 01 December 2019 Accepted: 31 December 2019 Published: 31 December 2019

\section{Publisher}

Horizon e-Publishing Group

\section{*Correspondence \\ Dipjyoti Chakraborty \\ \.dipjyoti@banasthali.in}

\begin{abstract}
Legumes are the most important source of food and fodder but due to climatic changes and global warming; crops are consistently exposed to environmental stresses such as low water shortage, high salinity, mineral toxicity and deficiency, extreme temperatures, etc. Drought is undoubtedly the major constraint limiting plant growth and crop productivity worldwide. The present study was conducted to assess the effect of drought on the growth of plant and productivity in three different mungbean varieties [Vigna radiata (L.) Wilczek] i.e. IPM 02-3, RMG 975 and IPM 02-14. The studied varieties exhibited significant variation in plant height, root length, pod length, pods/ plant, fresh weight of shoot, root and nodule, dry weight of shoot, root and nodule, number of leaves/plant, plant leaf area, relative leaf water content (RLWC) and initiation day of flowering. The effect of drought can better seen at the flowering stage and pod development stage that ultimately reduces crop productivity. The deleterious effect of drought in terms of morphophysiological properties studied as above was more prominent in the variety IPM 02-14 in comparison to RMG 975 and IPM 02-3. It can be concluded that varieties IPM 02-3 and RMG 975 are better adapted to drought condition.
\end{abstract}

Keywords: Mungbean; growth parameters; relative water content; water deficit stress.

Citation: Kumari D, Chakraborty D. Evaluation of mungbean [Vigna radiata (L.) Wilczek] varieties under water deficit stress Plant Science Today 2019;6(sp1):623-630. https://doi.org/10.14719/pst.2019.6.sp1.692

Copyright: (C) Kumari D and Chakraborty(2019). This is an open-access article distributed under the terms of the Creative Commons Attribution License, which permits unrestricted use, distribution, and reproduction in any medium, provided the original author and source are credited (https://creativecommons.org/licenses/by/4.0/).

Indexing: Plant Science Today is covered by Scopus, Web of Science, BIOSIS Previews, ESCI, CAS, AGRIS, UGC-CARE, CABI, Google Scholar, etc. Full list at http://www.plantsciencetoday.online

\section{Introduction}

Legume crops are the vital source to meet our daily nutritional requirement. Most of the Indian population is vegetarian in dietary habit and pulses play a major role in providing protein $(22 \%)$ and other daily required nutrients (1). Drought is an environmental condition when there is continuous loss of water by transpiration and soil water cannot replenish it (2). Drought being one of the major constraints causing more than 50\% yields loss to the mungbean production (3). The morphological, physiological and biological characteristics of plant in every growth stage are adversely affected by drought stress (4). According to the IPCC (Intergovernmental Panel on Climate Change) report, a serious threat to agriculture is water deficit (5). Water stress affected agricultural regions can undergo yield loss up to $50 \%$ or more and up to $45 \%$ of world agricultural area is covered by water deficit where $38 \%$ of the world population resides (6). The response of plant 
under drought stress is usually observed by studying the morphological and physiological parameters which are potential indicators of drought tolerance (7). Among all these parameters, fresh weight and water content are most affected parameters (8). The response towards the drought stress varies according to plant species and genotype, plant age, developmental stage and severity of drought (9, $10)$.

Mungbean, popularly known as Golden Bean, is a significant legume crop from the nutritional viewpoint grown in tropical and subtropical Asia especially for the vegetarian population (11). In India, it is the third most important crop that contains 59.9\% carbohydrate, $24.5 \%$ protein and $3 \%$ vitamins (12). The seeds of the crop are eaten as daal and leaves, green and dried stalk are used as fodder (13). It is a short duration crop (60-65 days), making it fit in mixed cropping systems and crop rotation (14). As water scarcity is major restraining factor for mungbean production in arid and semiarid regions, there is vital requirement to identify drought tolerant varieties (15). Mungbean is mostly grown in marginal lands which have limited sources for crop improvement, making it more susceptible to environmental constraints especially to drought (16). Over the years, efforts in systematic breeding program have led to the development of improved varieties of mungbean but because of several abiotic constraints the yield has not increased substantially. Water stress reduce the growth of mungbean at flowering and pod development stage that significantly affect the plant height, seed production, productivity and yield components (17).

The aim of this present work is to evaluate varieties of Vigna radiata, viz., RMG 975, IPM 02-3 and IPM 02-14 for their drought tolerance physiological attributes. Assessment of variable growth parameters and relative performance of mungbean varieties at early growth stage under short term drought stress would be helpful to identify the suitable variety in semi arid region that may be advantageous in breeding programme to develop the drought tolerant varieties.

\section{Materials and Methods}

\section{Plant Material}

The present study was conducted with three different varieties of mungbean namely [Vigna radiata (L.) Wilczek] cv. RMG 975, IPM 02-3 and IPM 02-14 during kharif season (July- September) 2017. The seeds of utilized varieties were obtained from Krishi Vigyan Kendra (KVK) Banasthali, Rajasthan. All the experiments were conducted at the Department of Bioscience and Biotechnology, Banasthali Vidyapith $\left(26.4083^{\circ} \mathrm{N}, 75.8649^{\circ} \mathrm{E}\right.$, mean temperature $30.2{ }^{\circ} \mathrm{C} \pm 2$ and rainfall $651 \mathrm{~mm}$ ).

\section{Soil characterization}

The soil for the plantation of each variety plant was obtained from KVK field, Banasthali Vidyapith campus. The collected soil was air dried and passed through sieve $(2 \mathrm{~mm})$. The following soil properties were determined: Electrical conductivity (EC) of the soil suspension was determined with an EC meter; $\mathrm{pH}$ of suspension with soil: water at the ratio of $2: 5(\mathrm{w} / \mathrm{v})$ was measured by using a $\mathrm{p}^{\mathrm{H}}$ meter; organic carbon was determined by Walkley and Black's wet oxidation method (1934), nitrogen (N) by Kjeldahl method, phosphorus (P) through molybdate-ascorbic acid procedure, available iron (Fe), copper $(\mathrm{Cu})$, manganese (Mn), and zinc (Zn) content determined using atomic absorption spectrophotometer (AAS). Available Sulphur in soil was determined by turbidometric method (18) and cation such as potassium (K) was also determined (19). The available Boron was estimated by spectrophotometric method (20).

\section{Plant cultivation and drought stress}

Surface sterilization of seeds was done by dipping seeds in $95 \%$ ethanol momentarily and then in 2.5$3 \%$ sodium hypochloride for 1-2 min. Then, the seeds were rinsed several times with autoclaved water, soaked in distilled water for the germination at $28 \pm 2^{\circ} \mathrm{C}$ for $24 \mathrm{~h}$. The germinated seeds of each variety were then planted in earthen pots (diameter-18 inch, height-22 inch); moistened with autoclaved distilled water and kept in plant growth chamber at $30 \pm 2^{\circ} \mathrm{C}$ under $16 / 8 \mathrm{~h}$ photoperiod and watered regularly. Short term water deficit stress was given to three week old plants by withholding water supply for 4 days then re-watered while control plants were allowed to grow and watered regularly under normal growth conditions.

\section{Physiological characteristics}

Plants were divided into two sets: Set 1 -well watered plants which were watered regularly and Set 2 -plants which were exposed to water deficit stress by with-holding water for four days from 24 DAS (Days after sowing) to 28 DAS. The plants were observed for wilting symptoms during drought stage and the time required for recovery noted. The $\%$ change in relative leaf water content (RLWC) was determined. Initiation day of flowering in well watered plants and drought stressed plants was recorded. The physiological parameters including plant height, root length, pod length, average number of pod/plant, nodule number, leaf number, leaf area, fresh weight of root, shoot and nodule, dry weight of root, shoot and nodule were noted at harvest.

\section{Leaf area}

Plant leaf area was recorded as per standard methods $(21,22)$. The leaf length and width was calculated and plant leaf area was measured by using formula: Leaf area $=0.74 \times 3 \times \mathrm{Ni}(\mathrm{L} \times \mathrm{W} \times \pi / 4)$ 
Where, $\mathrm{L}=$ length of the middle leaflet leaf $(\mathrm{cm}) ; \mathrm{W}$ $=$ width of the middle leaflet $(\mathrm{cm}) ; \pi: 3.1416 ; \mathrm{N}=$ number of leaves.

\section{Relative leaf water content (RLWC)}

Relative leaf water content (RLWC), an important factor determining the plant physiological water (23). It was determined by cutting the fully expanded top-most leaves and then weighed to attain the fresh weight. The fresh leaves were then soaked in water for $4 \mathrm{~h}$ in refrigerator. After $4 \mathrm{~h}$, to remove the water content, leaves were blotted with tissue paper and weighed to get the turgid weight. The turgid leaves were oven-dried at $80^{\circ} \mathrm{C}$ for $24 \mathrm{~h}$. The oven dried leaves were weighted to attain the dry weight of leaves. The relative leaf water content was determined using the formula: RLWC $(\%)=[(F W-D W) /(T W-D W)] \times 100$; where, $\mathrm{FW}=$ fresh weight of leaf; TW = turgid weight of leaf; DW = dry weight of leaf $(24,25)$.

\section{Statistical analyses}

The main effect of Variety and Treatment are statistically significant at 5\% level of significance. Analysis of Variance (ANOVA) - Duncan multiple range test (DMRT) was conducted to detect significant differences between means $(p<0.05)$ using SPSS software (20.0). After conducting post host test using LSD, the difference between varieties and their levels are statistically significant at $5 \%$ level of significance.

\section{Results and Discussion}

\section{Soil characteristics}

The soil characteristics studied are represented in Table 1 . The soil nutrients play a significant role in the plant growth productivity. A soil with enrich nutrients enhance the plant growth and soil fertility. Nutrients enrich soil also promotes root growth so that the plants capture available nutrients in sufficient amount (26). The soil used in the study was slightly alkaline in nature. The alkaline nature of soil is generally attributed to the presence of free lime (27). Also, at higher soil pH, the mineralization of organic matter increases (28). The electric conductivity (EC) was found 0.34 $\mathrm{dS}$ m-1 which was under normal range $(<1.0 \mathrm{dSm}$ $\left.{ }^{1}\right)$. The normal EC with light texture nature cause the leaching of salt to lower horizons (29). Organic carbon content $(<0.68 \%)$ and nitrogen $(<495.7 \mathrm{~kg}$ $\mathrm{ha}^{-1}$ ) was found to be low The available concentrations of P, K, and S (>15.6, >241.3 kg ha-1 and $>1.7 \mathrm{mg} \mathrm{kg}^{-1}$ ) are high respectively. The analyzed micronutrient $\mathrm{Fe}$ and $\mathrm{Cu}$ was low and the other micronutrients such as $\mathrm{Zn}, \mathrm{Mn}$ and $\mathrm{B}$ is sufficient for plant growth. Soil contains various trace elements to enhance the photosynthetic rate. Molybdenum (Mo) is efficient in nitrogen fixation and a component of nitrate reductase which heips in the production of ammonia $\left(\mathrm{NH}_{3}\right)$ from inorganic $\mathrm{NO}_{3}$ and its deficiency affects yield and growth of mungbean (30). Micronutrients along with $\mathrm{Fe}$, Mo and $\mathrm{Zn}$ increase the nodulation efficieny of mungbean so it also increases the nitrogen fixation and chlorophyll content in the leguminous plants (31). The soil collected from KVK field, Banasthali Vidyapith campus was filled in earthern pots (diameter: $7 \mathrm{~cm}$, height: $8 \mathrm{~cm}$ ) with germinated seeds of respective three varieties RMG 975, IPM 02-3 and IPM 02-14 and same environmental condition was given the plant varieties (Fig. 1). All the studied soil parameters indicate it to be suitable for plant growth (32).

\section{Physiological Properties}

Drought stress affects the plant growth and crop yield depending upon the plant variety and severity of stress (Fig. 2). Among the $V$. radiata varieties selected for the present study, the varieties IPM02-3 and RMG 975 were found to

Table 1. Physiochemical properties of the soil

\begin{tabular}{ll}
\hline \multicolumn{1}{c}{ Property } & Soil parameters \\
\hline EC $(\mathrm{ds} / \mathrm{m})$ & 0.34 (medium) \\
\hline Soil pH & 7.77 (slight alkaline) \\
\hline Organic carbon (\%) & 0.31 (low) \\
\hline Nitrogen $\left(\mathrm{kg} \mathrm{ha}^{-1}\right)$ & 196.50 (low) \\
\hline Phosphorous $\left(\mathrm{kg} \mathrm{ha}^{-1}\right)$ & 47.36 (high) \\
\hline Potassium $\left(\mathrm{kg} \mathrm{ha}^{-1}\right)$ & 537.60 (very high) \\
\hline Sulfur $\left(\mathrm{mg} \mathrm{kg}^{-1}\right)$ & 29.00 (high) \\
\hline Zinc $\left(\mathrm{mgkg}^{-1}\right)$ & 1.14 (sufficient) \\
\hline Iron $\left(\mathrm{mg} \mathrm{kg}^{-1}\right)$ & 3.02 (deficient) \\
\hline Manganese $\left(\mathrm{mg} \mathrm{kg}^{-1}\right)$ & 1.85 (deficient) \\
\hline Copper $\left(\mathrm{mg} \mathrm{kg}^{-1}\right)$ & 0.50 (deficient) \\
\hline Boron $\left(\mathrm{mg} \mathrm{kg}^{-1}\right)$ & 2.85 (sufficient)
\end{tabular}

exhibit better adaptation and lower physiological deterioration as compared to the variety IPM 02-14 when subjected to short term drought stress that eventually depicts their differential tolerance potential for the water deficit condition. It has been reported that some mungbean varieties are more drought tolerant, as they accumulate more osmoregulators which help to overcome the effect of drought $(2,33)$. The growth parameters were more prominent in well watered plants as compared to short term drought stressed plant in terms of morpho-physiological properties are represented in Table 2. The variety IPM 02-3 showed highest plant height both in well watered and drought stressed plants at harvesting time and the lowest plant height was noted in the variety IPM 02-14 under drought stress. According to a previous study (34), during drought stress, the cell growth as well as enlargement gets reduced due to low moisture availability.

Maximum root length was obtained in variety IPM 02-3 $(11.83 \mathrm{~cm})$ and minimum root length was attained in variety IPM 02-14 $(6.33 \mathrm{~cm})$ under drought stress. Thus, more wilting was observed during drought stress in this variety. It is reported that water deficit tolerant variety of mungbean averted more carbon to roots during stress condition (35). 
Water deficit stress reduced leaf number per plant. Among the plants exposed to drought stress, the maximum number of leaves per plant was noted in the variety IPM $02-3$ and the lowest was noted in IPM 02-14. It was reported that drought stress affect the leave number as well as leaf area development of mungbean (36). It is reported that varietal difference for leaf area measurement and dry mass at growth stage, could be correlated with genetic makeup of the varieties (37). Data represented in Table 2, reflects that in the well watered set, the variety IPM 02-3 has maximum number of pods per plant as well as pod length $(6.73 \mathrm{~cm})$ and under drought induced condition, IPM 02-14 has lower pod number and pod length $(4.93 \mathrm{~cm})$. It is previously reported that drought stress caused yield loss mainly by pod abortion (38). Variation in pod length of Mungbean varieties has also been reported Parvez et al. (39). The maximum pod length was noted under well watered conditions in the variety IPM 02-3 (6.73 $\mathrm{cm}$ ) and lowest pod length was noted in the drought induced variety IPM 02-14 $(4.93 \mathrm{~cm})$.

Average fresh weight (biomass) of shoot, root and root nodule decreased significantly in the plants subjected to drought stress. The maximum root, root nodule and shoot fresh weight were attained by variety IPM 02-3 under well water condition and minimum was noted among plants of variety IPM 02-14 under drought stress. The number of root nodules and biomass has been reported to be greatly reduced under drought stress in soybean (40). Thus, it is possible that IPM 02-3 and RMG 975 have greater drought tolerance potential than IPM 02-14. The dry weight of shoot, root and root nodule was recorded in well watered and drought stressed for all three mungbean varieties. The highest dry weight of root, nodule and shoot was recorded in well watered IPM 02-3 variety and least in drought stress treated IPM 0214 plant variety. The highest reduction in dry weight in IPM 02-14 indicates its sensitivity to drought. Some previous studies concluded that as water stress increased, the shoot dry matter was progressively reduced in mungbean (36). It is reported that well watered plants converted dry matter to grains and pods significantly while the drought induced plants converted dry matter to roots and shoots (41).

The highest number of nodules was recorded in IPM 02-3 under well watered conditions and minimum number of nodule was noted in IPM 02-14 when subjected to drought (Fig. 3 ). It is reported that nitrogen fixation capacity of leguminous plants decreases with environmental constrains such as drought (42) along with alteration in nodule structure and weight (43). The $\%$ decrease in nodule number was maximum in variety IPM 02-14 (31.69\%) and minimum in IPM $02-3(20.95 \%)$. Days to first flowering vary in different varieties and \% delay in flowering in drought stress was recorded in the plants. Because of late maturity, the first flowering day delayed in drought stressed plants as compared to well watered plants. The minimum \% delay in flowering was recorded $20 \%$ in IPM $02-3$ and maximum \% delay in flowering was observed in IPM 02-14 (27\%). It has been reported that the seed yield of mungbean had direct relation with flower production and flowering duration (44).

\section{Leaf area}

Drought was also found to have profound effect on plant leaf area which reduced on exposure to
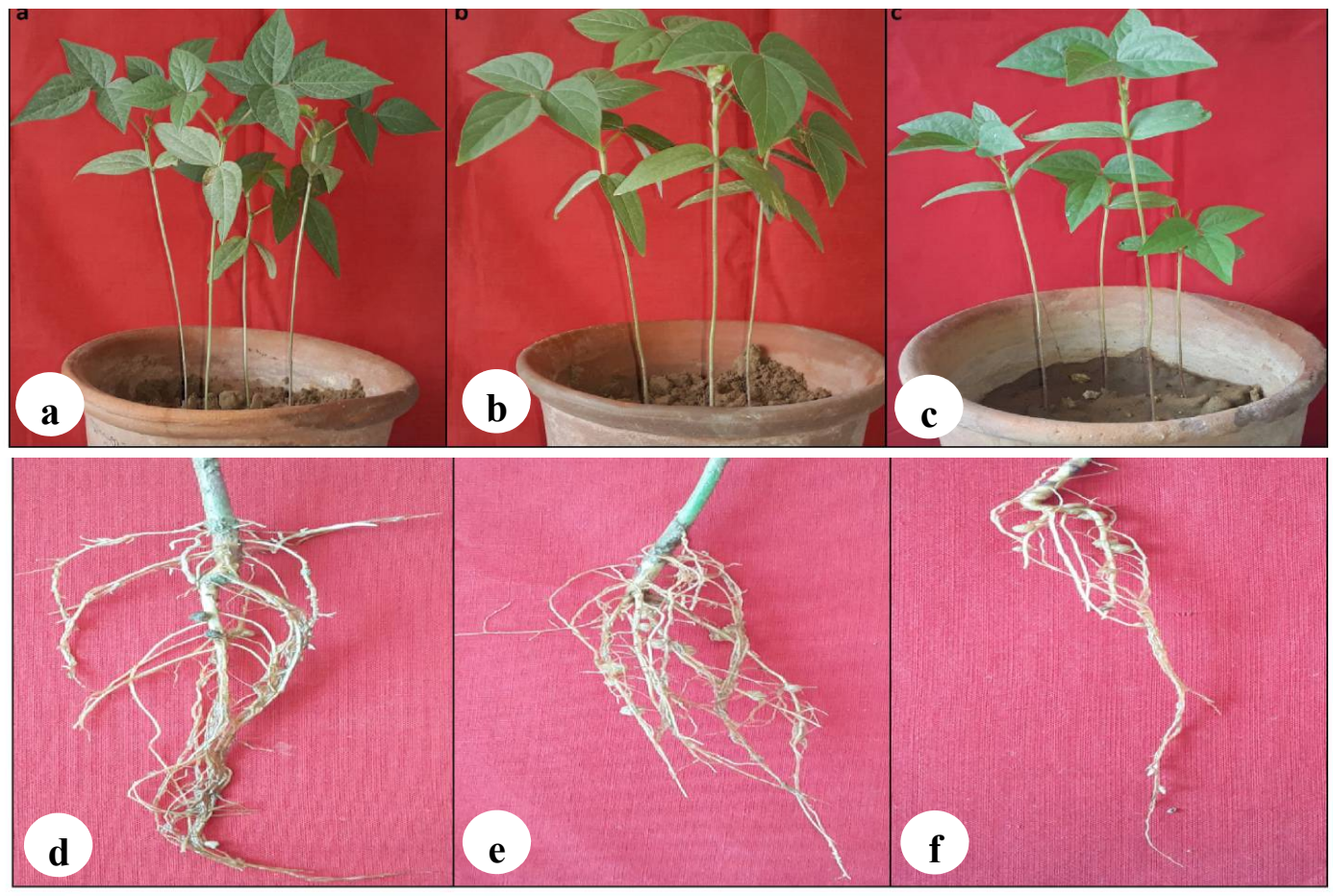

Fig. 1. Mungbean plants under well watered condition: 1(a)IPM 02-3, 1(b) RMG 975, 1(c) IPM 02-14 (d) root of IPM 02-3, 1(e) root of RMG 975, 1 (f) root of IPM 02-14. 

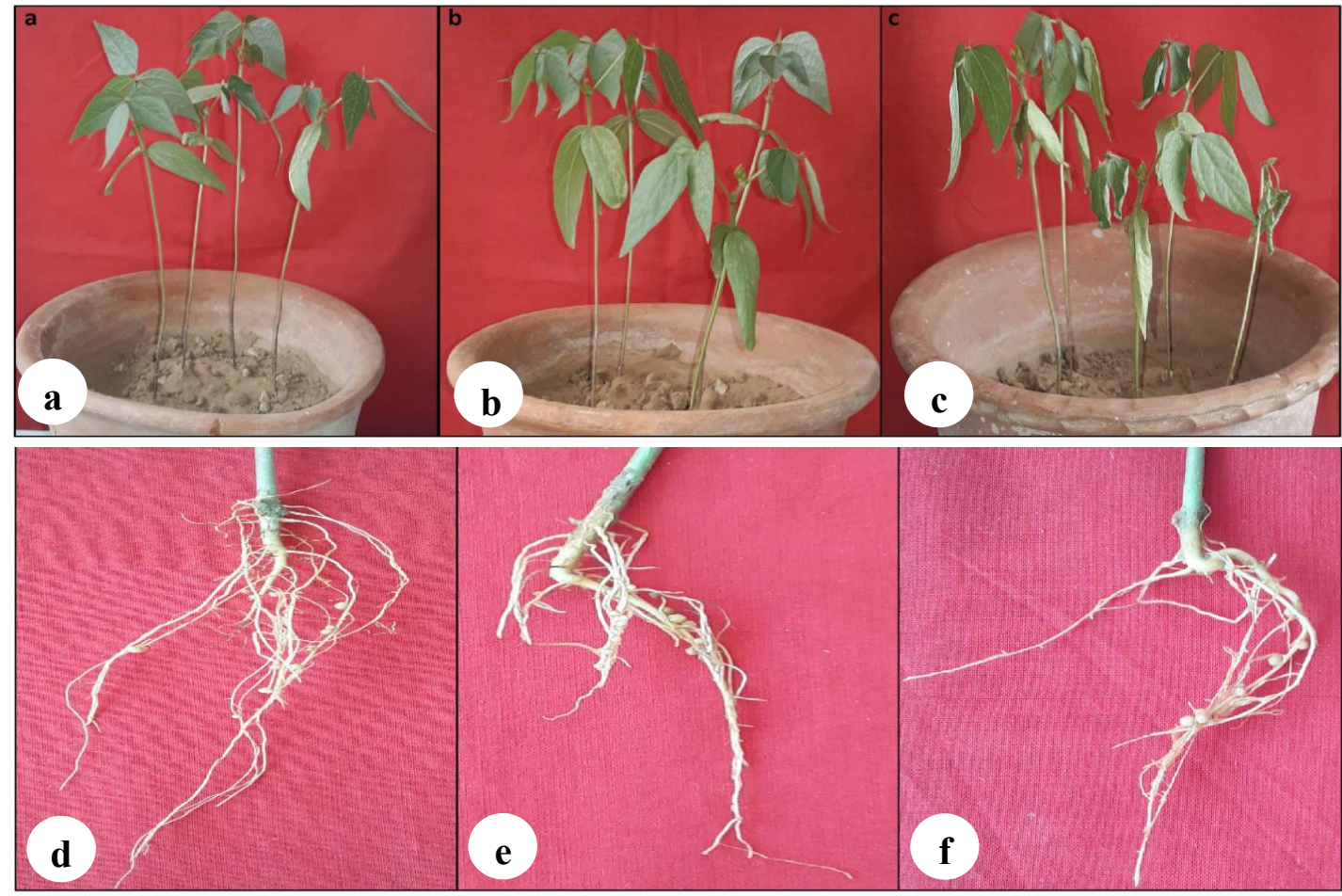

Fig. 2. Mungbean plants under drought stress condition: 2(a) IPM 02-3, 2(b) RMG 975, 2(c) IPM 02-14, 2(d) root of IPM 02-3, 2(e) root of RMG 975, 2(f) root of IPM 02-14.
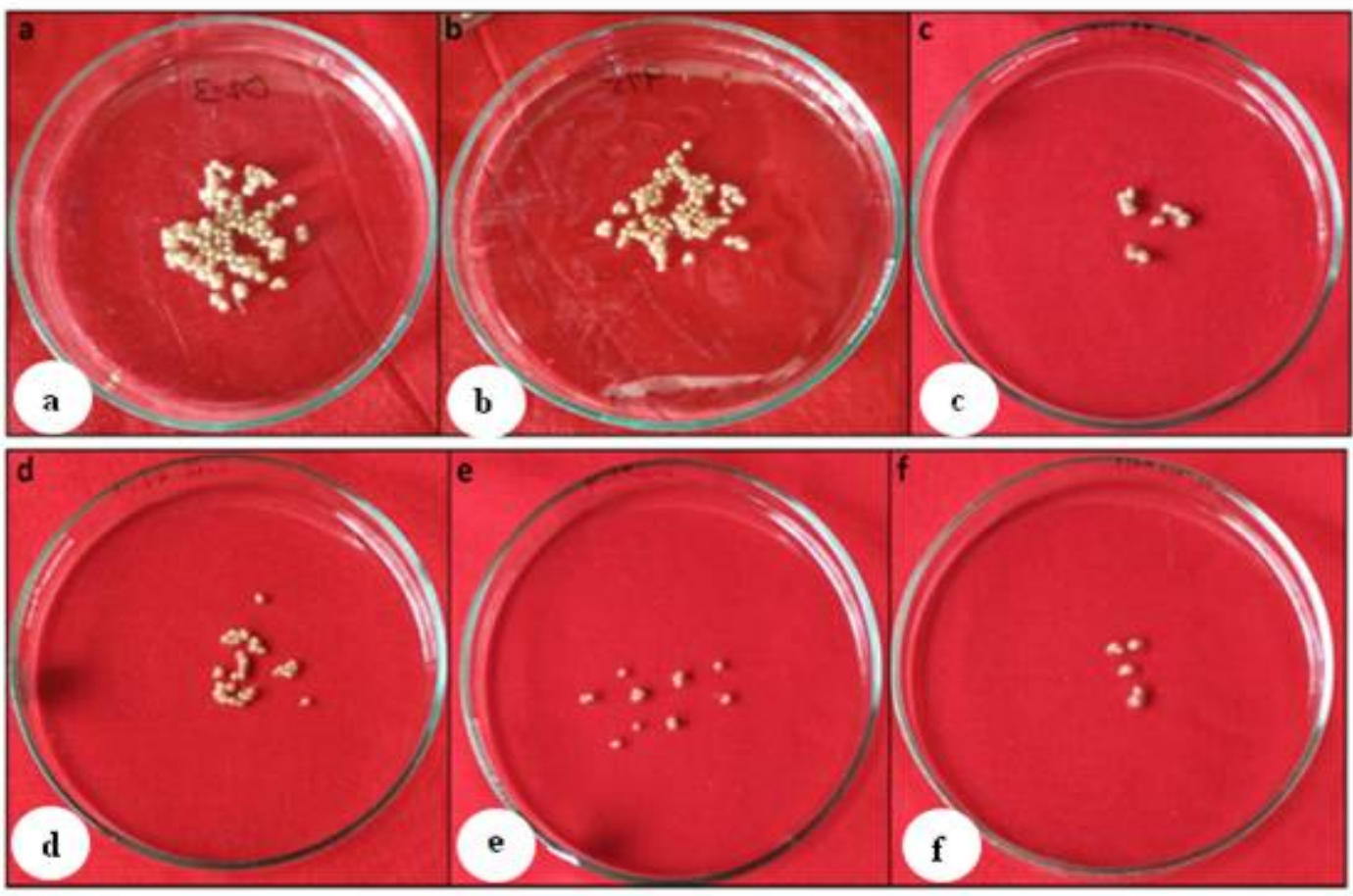

Fig. 3. Mungbean root nodules under well watered and drought stress conditions: 3(a) IPM 02-3, 3(b) RMG 975, 3(c) IPM 02-14, 3(d) drought stressed IPM 02-3, 3(e) drought stressed RMG 975, 3(f) drought stressed IPM 02-14.

drought stress. Earlier conducted study has also reported reduction in plant leaf area due to water deficit (45). The highest leaf area under well watered condition was obtained in variety IPM $02-$ $3\left(30.84 \mathrm{~cm}^{2}\right)$ and lowest was in IPM 02-14 (21.48 $\mathrm{cm}^{2}$ ). Same as with drought stressed plants-the highest was obtained in variety IPM 02-3 (23.20 $\mathrm{cm}^{2}$ ) and lowest in variety IPM 02-14 $\left(19.17 \mathrm{~cm}^{2}\right)$. It is reported that the decrease in leaf area is due to the decrease in cell number and cell size reduction under drought stress $(46,47)$.

\section{Relative leaf water content}

Degree of drought stress is calculated by measuring the Relative leaf water content of the plant that helps to evaluate a plant's water status under normal or drought conditions. The $\%$ decrease in RLWC with respect to well watered 
Table 2. Growth parameters of IPM 02-3, RMG975 and IPM 02-14 at plant harvesting stage. Results are mean \pm standard deviation $(\mathrm{SD})$, data followed by same alphabets in a row are not significant at $\mathrm{P}=0.05$ )

\begin{tabular}{|c|c|c|c|c|c|c|}
\hline \multirow{3}{*}{ Characters } & \multicolumn{6}{|c|}{ Varieties } \\
\hline & \multicolumn{2}{|c|}{ IPM 02-3 (0) } & \multicolumn{2}{|c|}{ RMG 975 (1) } & \multicolumn{2}{|c|}{ IPM 02-14 (2) } \\
\hline & Control & Drought & Control & Drought & Control & Drought \\
\hline Plant Height (cm) & $36.33 \pm 0.57^{c}$ & $35.66 \pm 0.28^{c}$ & $36.00 \pm 0.50^{c}$ & $33.50 \pm 0.50^{\mathrm{b}}$ & $30.70 \pm 0.15^{\mathrm{a}}$ & $29.83 \pm 0.76^{\mathrm{a}}$ \\
\hline Root Length (cm) & $11.83 \pm 0.76^{\mathrm{c}}$ & $11.50 \pm 0.50^{c}$ & $11.50 \pm 0.50^{c}$ & $11.43 \pm 0.40^{\mathrm{c}}$ & $8.33 \pm 0.57^{b}$ & $6.33 \pm 0.57^{\mathrm{a}}$ \\
\hline Leaf Area $\left(\mathrm{cm}^{2}\right)$ & $30.84 \pm 0.19^{d}$ & $23.20 \pm 1.02^{\mathrm{c}}$ & $29.47 \pm 0.57^{\mathrm{d}}$ & $21.07 \pm 1.09^{b}$ & $21.48 \pm 1.77^{\mathrm{bc}}$ & $19.17 \pm 0.69^{\mathrm{a}}$ \\
\hline Leaf number/plant & $13.66 \pm 0.57^{c}$ & $9.33 \pm 0.57^{\mathrm{a}}$ & $11.33 \pm 0.57^{b}$ & $9.00 \pm 1.00^{\mathrm{a}}$ & $9.33 \pm 0.57^{\mathrm{a}}$ & $8.33 \pm 1.15^{\mathrm{a}}$ \\
\hline Pod per plant & $8.33 \pm 0.57^{c}$ & $5.66 \pm 0.57^{\mathrm{b}}$ & $6.66 \pm 0.57^{\mathrm{b}}$ & $5.66 \pm 0.57^{b}$ & $3.66 \pm 0.57^{\mathrm{a}}$ & $2.66 \pm 0.57^{\mathrm{a}}$ \\
\hline Pod Length (cm) & $6.73 \pm 0.11^{\mathrm{d}}$ & $5.63 \pm 0.23^{b}$ & $6.16 \pm 0.11^{\mathrm{c}}$ & $5.20 \pm 0.43^{\mathrm{a}}$ & $5.16 \pm 0.15^{\mathrm{a}}$ & $4.93 \pm 0.20^{\mathrm{a}}$ \\
\hline Nodule number & $22.66 \pm 1.15^{\mathrm{e}}$ & $16.00 \pm 1.00^{c}$ & $20.00 \pm 1.00^{\mathrm{d}}$ & $16.33 \pm 0.57^{\mathrm{c}}$ & $13.66 \pm 0.57^{b}$ & $9.33 \pm 0.57^{\mathrm{a}}$ \\
\hline FW Shoot (gm) & $2.47 \pm 0.07^{\mathrm{d}}$ & $2.20 \pm 0.08^{c}$ & $2.45 \pm 0.04^{\mathrm{d}}$ & $2.08 \pm 0.05^{c}$ & $1.94 \pm 0.10^{\mathrm{b}}$ & $1.32 \pm 0.07^{\mathrm{a}}$ \\
\hline FW Root (gm) & $0.39 \pm 0.01^{b}$ & $0.26 \pm 0.03^{\mathrm{a}}$ & $0.37 \pm 0.03^{b}$ & $0.25 \pm 0.02^{\mathrm{a}}$ & $0.24 \pm 0.04^{\mathrm{a}}$ & $0.22 \pm 0.00^{\mathrm{a}}$ \\
\hline FW Nodule (gm) & $0.16 \pm 0.00^{\mathrm{e}}$ & $0.09 \pm 0.00^{c}$ & $0.16 \pm 0.00^{\mathrm{e}}$ & $0.08 \pm 0.00^{b}$ & $0.11 \pm 0.00^{\mathrm{d}}$ & $0.06 \pm 0.00^{\mathrm{a}}$ \\
\hline DW Shoot (gm) & $0.74 \pm 0.05^{b}$ & $0.62 \pm 0.09^{\mathrm{b}}$ & $0.71 \pm 0.07^{\mathrm{b}}$ & $0.40 \pm 0.05^{\mathrm{a}}$ & $0.41 \pm 0.09^{\mathrm{a}}$ & $0.38 \pm 0.07^{\mathrm{a}}$ \\
\hline DW Root (gm) & $0.09 \pm 0.00^{\mathrm{d}}$ & $0.07 \pm 0.00^{\mathrm{b}}$ & $0.08 \pm 0.00^{c}$ & $0.08 \pm 0.00^{\mathrm{bc}}$ & $0.07 \pm 0.00^{\mathrm{b}}$ & $0.06 \pm 0.00^{\mathrm{a}}$ \\
\hline DW Nodule (gm) & $0.018 \pm 0.000^{c}$ & $0.013 \pm 0.001^{b}$ & $0.017 \pm 0.001^{c}$ & $0.009 \pm 0.000^{\mathrm{a}}$ & $0.009 \pm 0.001^{\mathrm{a}}$ & $0.008 \pm 0.001^{\mathrm{a}}$ \\
\hline LRWC & $86.73 \pm 1.92^{c}$ & $84.83 \pm 1.66^{\mathrm{c}}$ & $85.00 \pm 1.60^{c}$ & $79.63 \pm 3.09^{b}$ & $76.16 \pm 1.04^{b}$ & $64.23 \pm 2.12^{\mathrm{a}}$ \\
\hline Flowering time (Days) & 35 & 42 & 34 & 43 & 37 & 47 \\
\hline
\end{tabular}

plants was highest in variety IPM 02-14 (15.66\%) and lowest was in IPM 02-3 (2.10\%). Reduced RLWC values illustrate that physiological activity of plant might be affected by adverse water deficit conditions, which could also affect the plant photosynthetic rate (48). So, the non-stressed plants have higher RWC than stressed plants (49). The highest leaf relative water content was found in well watered IPM 02-3 and lowest was found in drought stressed variety IPM 02-14.

\section{Conclusion}

In the present work, all the three varieties gave significantly different morphological and physiological parameters under same environmental conditions. The soil used for the study had all the macronutrients and micro nutrients required for the plant growth productivity. After evaluation of three varieties with respect to their performance under short term drought stress, IPM 02-3 and RMG 975 were found to be most tolerant and promising varieties and the variety IPM $02-14$ is sensitive to drought stress. This present findings can be utilized in plant breeding programmes to better adapted plants for possible cross-inoculation to increase productivity of leguminous plants under drought stress condition. The present study indicates that growth rate, morphological and physiological parameters can be used successfully to evaluate drought sensitive and resistant varieties.

\section{Acknowledgements}

The authors are grateful to Prof. Aditya Shastri, Vice Chancellor, Banasthali Vidyapith for providing all necessary support. We acknowledge the Bioinformatics Centre, Banasthali Vidyapith supported by DBT for providing computation support, and DST for providing networking and equipment support through the FIST and CURIE programmes at the Department of Bioscience and Biotechnology. CESME, Banasthali Vidyapith, supported by MHRD, Government of India under the PMMMNMTT is acknowledged for organizing the symposium.

\section{Competing interests}

The authors declare that they have no competing interests.

\section{Authors' Contribution}

DK drafted the manuscript with the collection of references. DC designed the concept, discussed the findings with scientific justification and over all edited the whole manuscript.

\section{References}

1. Singh R, Singh MK, Singh AK, Singh C. Pulses production in India: Issues and elucidations. Pharma Innov. 2018;7(1):10-13. ISSN (E): 2277- 7695. 
2. Bharadwaj N, Gogoi N, Barthakur S, Basumatary N Morpho-physiological responses in different mungbean genotypes under drought stress. Res J Recent Sci. 2018;7(7):1-5. ISSN 2277-502.

3. Gaur PM, Jukanti AK, Samineni S, Chaturvedi SK, Basu PS, Babbar A, et al. Climate change and heat stress tolerance in chickpea. In Climate Change and Plant Abiotic Stress Tolerance; Tuteja N, SS Gill, Eds. Wiley Blackwell:Weinheim, Germany. 2012;839-55. https://doi.org/10.1002/9783527675265.ch31

4. Basu S, Ramegowda V, Kumar A, Pereira A. Plant adaptation to drought stress. F1000 Res. 2016;5. https://doi.org/10.12688/f1000research.7678.1

5. IPCC. Climate Change Synthesis Report Contribution of Working Groups I. II and III to the Fifth Assessment Report of the Intergovernmental Panel on Climate Change. Geneva: IPCC, 151; 2014.

6. Bot AJ, Nachtergaele FO, Young A. Land resource potential and constraints at regional and country levels World Soil Resources Reports 90. Land and Water Development Division, FAO, Rome, Italy; 2000.

7. Sircelj H, Tausz M, Grill D, Batic F. Detecting different levels of drought stress in apple trees (Malus domestica Borkh.) with selected biochemical and physiological parameters. Sci Hort. 2007;113(4):362-69. https://doi.org/10.1016/j.scienta.2007.04.012

8. Jaleel CA, Manivannan P, Wahid A, Farooq M, Al-juburi HJ, Somasundaram R, Panneerselvam R. Drought stress in plants: a review on morphological characteristics and pigments composition. Int J Agric Biol. 2009;11:100-05. ISSN Online: 1814-9596.

9. Alpert P, Oliver MJ. Drying without dying. In: Desiccation and survival in plants: drying without dying. Black $\mathrm{M}$, Pritchard HW (eds). CABI publishing, Oxford and New York; 2002, pp. 1-45.

10. Walters C, Farrant JM, Pammenter NW, Berjak P. Desiccation stress and damage. In: Desiccation and survivalin plants: drying without dying. Black M, Pritchard HW (eds). CABI publishing, Oxford and New York; 2002, pp 263-93. https://doi.org/10.1079/9780851995342.0263

11. Kumari D, Chakraborty D. Drought stress mitigation in Vigna radiata by the application of root-nodulating bacteria. Plant Sci Today. 2017;4(4):209-12. https://doi.org/10.14719/pst.2017.4.4.343

12. Afzal MA, Murshad ANMMM, Bakar MA, Hamid A, Salahuddin ABM. Mungbean cultivation in Bangladesh, Pulse Research Station, Bangladesh Agricultural Research Institute, Gazipur, Bangladesh; 2008.

13. Singh DP, Ahlawat IPS. Greengram (Vigna radiata) and blackgram (V. mungo) improvement in India: past, present and future prospects. Indian J Agric Sci. 2005;75(5):243-50.

14. Timsina J, Connor DJ. Productivity and management of rice-wheat cropping systems: Issues and challenges. Field Crops Res. 2001;69:93-132. https://doi.org/10.1016/S0378-4290(00)00143-X

15. Pandey V, Shukla A. Acclimation and tolerance strategies of rice under drought stress. Rice Sci. 2015;22:147-61. https://doi.org/10.1016/j.rsci.2015.04.001

16. Singh DP, Singh BB. Breeding for tolerance to abiotic stresses in mungbean. J Food Legumes. 2011;24(2):83-90. Online ISSN: 0976-2434.

17. Sharma A, Dhanda S. Abiotic stress response in Vigna radiata L. (Mungbean). Int J Life Sci Biotechnol. Pharma Res. 2014;3(4):2250-3137.

18. Williams $\mathrm{CH}$, Steinberg's A. Soil sulphur fraction as chemical indices of available sulphur in some Australian soil. Aust J Agric Res. 1969;10:340-52. https://doi.org/10.1071/AR9590340
19. Kitagawa Y, Yanai J, Nakao A. Evaluation of non exchangeable potassium content of agricultural soils in Japan by the boiling $\mathrm{HNO}_{3}$ extraction method in comparison with exchangeable potassium. Soil Sci Plant Nutr. https://doi.org/10.1080/00380768.2017.1411168

20. Wear JI. Boron. In: Methods of Soil Analysis (C.A. Black et al., Eds.), Part II. American Society of Agronomy, Madison, Winconsin, USA; 1965.

21. Ambede JG, Netondo GW, Mwai GN, Musyimi DM. NaCl salinity affects germination, growth, physiology and biochemistry of bambara groundnut. Braz J Plant Physiol. 2012;24(3):151-60. https://doi.org/10.1590/S1677-04202012000300002

22. Chaudhary S, Chakraborty D. Screening of Vigna mungo (L.) Hepper varieties under drought stress. Plant Cell $\begin{array}{llll}\text { Biotechnol Mol Biol. } & \text { 2019;20(1-2):35-46. }\end{array}$ http://www.ikprress.org/index.php/PCBMB/article/view/4328

23. Makbul S, Saruhanguler N, Durmus N, Guven S. Changes in anatomical and physiological parameters of soybean under drought stress. Turk J Bot. 2011;35:369-77. https://doi.org/10.3906/bot-1002-07

24. Yang JY, Zheng W, Tian Y. Effects of various mixed saltalkaline stresses on growth, photosynthesis, and photosynthetic pigment concentrations of Medicago ruthenica seedlings. Photosynthetica. 2011;49:275-84 https://doi.org/10.1007/s11099-011-0037-8

25. Hayatu M, Muhammad SY, Habibu UA. Effect of water stress on the leaf relative water content and yield of some Cowpea (Vigna unguiculata L. walp) genotypes. Int J Sci Technol Res. 2014;3(7):148-52. ISSN 2277-8616.

26. White PJ, George TS, Dupuy LX, Karley AJ, Valentine TA, Wiesel L, Wishart J. Root traits for infertile soils. Front Plant Sci. 2013a;4:193. https://doi.org/10.3389/fpls.2013.00193

27. Jibhkate SB, Bhende SN, Kharche VK, Selvalakshmi V. Physico-chemical status of Katoltahsil in Nagpur district. J Soils Crop. 2009;19(1):122-128. E-ISSN: 2321-4902.

28. Neina D. The role of soil $\mathrm{pH}$ in plant nutrition and soil remediation. Appl Environ Soil Sci. 2019;1-9. https://doi.org/10.1155/2019/5794869

29. Singh C, Bajpai RK, Tiwari A, Chandra M, Krishna B. Evaluations of soil fertility status of available major nutrients (N, P \& K) and micro nutrients (Fe, Mn, Cu \& Zn) in Vertisol of Balodabazar block in Balodabazar district of Chhattisgarh. J Pharmacogn Phytochem. 2018;2:10-12. PISSN: 2349-8234.

30. Srinivasan S, Selvi RV, Ramesh S, Pandiyan M, Sunder M, Kannan R, et al. Response of mungbean to different methods and levels of molybdenum application under acid soil conditions. Acta Hortic. 2007;752:473-76. https://doi.org/10.17660/ActaHortic.2007.752.86

31. Jamal A, Khan MI, Tariq M, Fawad M. response of mung bean crop to different levels of applied Iron and Zinc. J Hortic Plant Res. 2018;3:13-22. https://doi.org/10.18052/www.scipress.com/JHPR.3.13

32. Singh KS, Athokpam H. Physico-chemical characterization of farmland soil in some villages of Chandel Hill District, Manipur (India). Int J Curr Microbiol Appl Sci. 2018; 7(2):417-25. https://doi.org/10.20546/ijcmas.2018.702.053

33. Chowdhaury P, Sharma A, Syed Z, Agarwal D. Tissue specific drought stress response in different varieties of Mungbean (Vigna radiata (L) Wilczek) of Rajasthan. Int J Agric Environ Biotechnol. 2018;11(3):489-95. https://doi.org/10.30954/0974-1712.06.2018.10

34. Pandey S, Chakraborty D. Agro-morphological response of three Vigna mungo varieties (T9, RBU38 and VM4) to soil water deficit. Int J Sci Res Agric Sci. 2016;3(2):036-41. https://doi.org/10.14719/pst.2015.2.2.99 
35. Sangakkaran UR, Frehner M, Nosberger J. Effect of soil moisture and potassium fertilizer on shoot water potential, photosynthesis and partitioning of carbon in mungbean and cowpea. J Agron Crop Sci. 2000;185:201-07. https://doi.org/10.1046/j.1439-037x.2000.00422.x

36. Ranawake AL, Amarasingha UGS, Rodrigo WDRJ, Rodrigo UTD. Dahanayaka N. Effect of water stress on growth and yield of mungbean (Vigna radiata L). Trop Agric Res Exten. 2011;14(4):76-79. https://doi.org/10.4038/tare.v14i4.4851

37. Mondal MMA, Puteh AB, Malek MA, Ismail MR, Rafii MY, Latif MA. Seed Yield of Mungbean [Vigna radiata (L.) Wilczek] in relation to growth and developmental aspects. Sci World J. 2012;1-7. https://doi.org/10.1100/2012/425168

38. Lie F, Andersen MN, Jensen CR. Loss of pod set caused by drought stress is associated with water status and ABA content of reproductive structures in soybean. Funct Plant Biol. 2003;30:271-80. https://doi.org/10.1071/FP02185

39. Parvez MT, Paul SK, Sarkar MAR. Yield and yield contributing characters of mungbean as affected by variety and level of phosphorus. J Agroforest. Environ. 2013;7(1):115- 118. ISSN 1995-6983.

40. King CA, Purcell C. Soybean nodule size and relationship to nitrogen fixation response to water deficit. Crop Sci. 2001; 41:1099-107. https://doi.org/10.2135/cropsci2001.4141099x

41. Kumar A, Sharma KD. Physiological responses and dry matter partitioning of summer mungbean (Vigna radiata L.) Genotypes subjected to drought conditions. J Agron Crop Sci. 2009;95:270-77. https://doi.org/10.1111/j.1439-037X.2009.00373.X

42. Arrese-Igor C, Gonzalez EM, Marino D, Ladrera R, Larrainzar E, Gil-Quintana E. Physiological responses of legume nodules to drought. Plant Stress. 2011;24-31.
43. Ramos MLG, Parsons R, Sprent JI, James EK. Effect of water stress on nitrogen fixation and nodule structure of common bean. Pesqui. Agropecu. Bras. 2003;38:339-47. https://doi.org/10.1590/S0100-204X2003000300002

44. Mondal MMA, Fakir MSA, Juraimi AS, Hakim MA, Islam MM, Shamsuddoha ATM. Effects of flowering behavior and pod maturity synchrony on yield of mungbean [Vigna radiata (L.) Wilczek]. Aust J Crop Sci. 2011;5:945-953. ISSN:1835-2707.

45. Sankar B, Gopinathan P, Karthishwaran K, Somasundaram R. Variation in growth of peanut plants under drought stress condition and in combination with paclobutrazol and abscisic acid. Curr Bot. 2014;5:14-21.

46. Bhatt RM, Rao S. Influence of pod load response of okra to water stress. Indian J Plant Physiol. 2005;10:54-59.

47. Kusaka M, Ohta M, Fujimura T. Contribution of inorganic compounds to osmotic adjustment and leaf folding for drought tolerance in pearl millet. Physiol. Plant. 2005;125: 474-89. https://doi.org/10.1111/j.1399-3054.2005.00578.x

48. Costa-Franca MG, Pham-Thi AT, Pimentel C, PereyraRossiello RO, Zuily-Fodil Y, Laffray D. Differences in growth and water relations among Phaseolus vulgaris cultivars in response to induced drought stress. Environ Exp Bot. 2000 43:227-37. https://doi.org/10.1016/S0098-8472(99)00060-X

49. Ahmadizadeh M. Physiological and agro-morphological response to drought stress. Middle-East J Sci Res. 2013;13: 998-1009. https://doi.org/10.5829/idosi.mejsr.2013.13.8.3531 